\title{
Electoral corruption unfolded by Operation Car Wash and political rights in Brazil
}

\author{
Michael Freitas Mohallem \\ Getulio Vargas Foundation Law School, Rio de Janeiro, Brazil
}

\begin{abstract}
Purpose - This article aims to advance the literature on the effects of corruption and its relationship to human rights violations. The article also presents an overview of existing legislative measures as well as those expected to be implemented at the national level to tackle corruption and its impacts on fundamental rights. Design/methodology/ approach - The study draws on the literature that addresses the relation between corruption and human rights, and analyses a single well-known case in Brazil (Operation Car Wash) in order to discuss both the violation of citizens' political rights and of those being investigated.

Findings - The article suggests that the Brazilian State has failed to guarantee fundamental rights as well as to effectively control electoral corruption. By exploring the complex structure of illegal campaign financing in Brazil, the article exposes how Operation Car Wash evidenced the violation of both of the right to participate public affairs and to vote in authentic elections in Brazil.

Originality/value - Considering that the literature shows it is difficult to link the breaches of human rights with incidences of corruption, this article debates the macro context in which the Car Wash case is inserted and demonstrates the evidence that link the corrupt acts involved in this operation to the violation of specific fundamental human rights: the political rights.
\end{abstract}

Keywords Corruption, Brazil, Elections, Human rights, Political rights, Operation Car Wash

Paper type Research paper

\section{Introduction}

This paper argues that Brazil has failed to guarantee civil and political rights enshrined by the country's human rights treaties due to its inability to prevent large scale electoral corruption. It focuses on Operation Car Wash, the largest corruption case in Brazil's history, and its unprecedent impact on national and international politics.

In 2014, Brazil witnessed the beginning of an investigation reaching all main political parties, the largest companies in the construction industry as well as Petrobras, Brazil's giant state-owned oil enterprise. The scheme maintained a broad agreement among the political parties that supported the governments during that period. It is estimated that the scheme began around 2004 and public agents who were in decision-making positions in Petrobras maintained sham competition among the large construction companies, which actually formed a cartel. On the other hand, private companies systematically offered generous donations to almost all parties - ruling and opposing parties - in electoral periods, both via official donations and slush funds.

(C) Michael Freitas Mohallem. Published in Public Administration and Policy. Published by Emerald Publishing Limited. This article is published under the Creative Commons Attribution (CC BY 4.0) license. Anyone may reproduce, distribute, translate and create derivative works of this article (for both commercial and non-commercial purposes), subject to full attribution to the original publication and authors. The full terms of this license may be seen at http://creativecommons.org/licences/by/4.0/ legalcode

This paper is part of a more comprehensive research on Operation Car Wash, its legacies, and learnings for fighting corruption. The research was funded by FGV's Applied Research and Knowledge Network. The author wishes to thank the anonymous reviewers of this manuscript for their suggestions.
Electoral corruption and political rights

Received 31 December 2020 Revised 22 February 2021 Accepted 2 March 2021
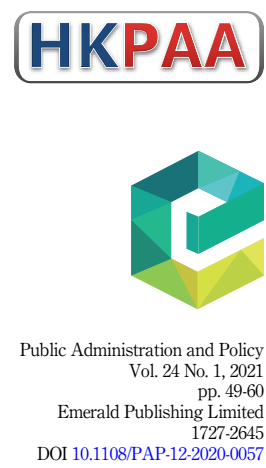
PAP

24,1

The effects of corruption are perceived in different ways in contemporary societies: in economic activity, in access to social rights and in democratic processes. Different examples of corruption illustrate the ways private companies feel convinced that their competitors are corrupt. These examples also explain how public services can suffer due to lack of public resources lost to corruption. The impact on democracy, though, is not easily measured in local corruption cases. They may affect specific political forces or temporarily frustrate parts of the electorate, but most electoral corruption cases do not sufficiently affect the political rights of an entire nation.

Brazil's Car Wash corruption scandal, however, is a rare case that changed the paradigm of electoral corruption by affecting the people's political rights in national elections. The scale and plurality of political actors impacted Brazilian democracy to an extent that the political rights of its citizens were violated. This case carries all the necessary legal elements to be brought before a human rights tribunal.

In Brazil, despite the perception of extensive political corruption, the attention lies on the causes, not the effects of bribery. The central focus in the public debate is the inefficiency of the justice system. Impunity - which includes the low rate of criminal convictions in general and of corruption specifically - is viewed by many as the cause for the failure in the fight against corruption. According to Avritzer and Filgueiras (2011, pp. 26-27), "the judiciary has proved to be inefficient towards corruption, particularly concerning crimes involving privileged jurisdiction. Despite the succession of cases of corruption in Brazilian public life, the rate of criminal convictions is low, which creates a sense of impunity that hangs over Brazilian politics."

According to this view, recent legislative reforms have offered new and more effective investigative tools to the police and prosecutors, but have failed to alter the Brazilian Judiciary's slowness and inability to punish. According to Lorente (2016, pp. 245-246), "the greater transparency of the Brazilian government has made it easier to uncover corruption in the public sphere, but it did not make up for the deficiencies of the judiciary, which remains slow in the trial process."

The perception that seems to prevail - which was clearly shown during the electoral process in 2018 - is that the practice of corruption is an element of political immobility, of stagnation and of restraining access of new political agents supposedly capable of acting with integrity. When political agents who acquire competitive advantage in the electoral process using illegal resources are not punished, this leads to long career as elected politicians, or at least to greater chances of success.

The literature on corruption indicates, therefore, impunity as one of the main elements for the perpetuation of corrupt practices. This article intends to advance this discussion in order to approach corruption from two new perspectives: (a) the analysis of the effects of corruption and its relationship with the violation of human rights, especially political rights of Brazilian citizens; and (b) an overview of the legislative measures already adopted as well as those expected at the national level to tackle corruption and its impacts on fundamental rights. To do so, the article mobilizes the literature that addresses the relation between corruption and human rights, and analyses a single well-known case (Operation Car Wash) in order to approach both the discussion of citizens' political rights violations and of those being investigated.

Although the emphasis on the judiciary as protector of political integrity shows how institutions in the fight against corruption are given excessive expectations and, in turn, downplays the responsibilities of individuals and their political choices, it also recognizes the impact of corruption on political rights. To be discussed below, in identifying structural obstacles in the competition between political parties, which are largely fuelled by corruption, the problem is transferred from the sphere of mere political choice to the field of political 
rights, in which the Judiciary is naturally expected to act. That is precisely why it is so important to analyse the legislative and judiciary measures adopted.

Operation Car Wash will be explored in order to approach the relationship between a subset of human rights and the corruption perpetrated by public agents in recent times, political parties and large companies in the Brazilian civil construction market. According to the Federal Prosecutor's Office (n.d.), "Operation Car Wash is the largest investigation of corruption and money laundering Brazil has ever had. It is estimated that the volume of resources diverted from Petrobras, the biggest state-owned company in the country, is around billions of reais (Brazilian currency). Besides, there is the economic and political expression of those suspected of participating in the corruption scheme that involves the company. In this scheme, which lasted for at least ten years, large contractors organized in a cartel and paid bribes to bureaucratic executives and other public officials. The amount of the bribe varied from $1 \%$ to $5 \%$ of the total amount of overpriced billion-dollar contracts, which was distributed through financial operators, including dollar dealers investigated in the first stage."

The article first presents Brazil's legislative framework on corruption and human rights, focusing on the international law adopted by Brazilian system. This section details corruption and human rights from a legislative perspective and briefly discuss how the literature explores the causes of corruption in Brazil.

The second section will discuss the relation between corruption and human rights, and the impact on political participation, using mainly the Car Wash case as a reference. It then focuses on civil and political rights, more specifically the rights: (a) to participate in public affairs; and (b) to vote in authentic elections. Thus, it is argued that the Brazilian State has failed to guarantee such rights by not preventing the dissemination of illegal financial resources in national and local elections over the last decades. Finally, this section makes a brief allusion to the possibility of investigating the violation of citizens' political rights.

Finally, the consequences of Operation Car Wash will be evaluated, and some recommendations will be proposed.

\section{The anti-corruption and human rights developments in Brazil}

In recent years, Brazil went through intense transformations in terms of dealing with corruption. One decade of significant legislative reforms resulted, among other statutes, in the Clean Slate Act (Law No. 135/2010), which rendered candidates ineligible for eight years if they renounced their mandates to avoid being removed from office, who were removed or who have been convicted by a collegiate decision of a court of law, even if it can still be reversed through appeals; the Organized Crime Act (Law No. 12,850/2013), which details the rewarded denunciation procedure: "the expansion of the use of rewarded denunciation can be attributed both to the greater precision of the applicable rules and to a cultural change that public authorities involved in the investigation underwent" (Mohallem and Ragazzo, 2017, p. 58); the Anti-Corruption Act (Law No. 12.846/2013), which establishes the possibility of legal and civil liability of legal entities; and the Freedom of Information Act (Law No. 12,527/2011). This new legal framework became the basis for investigations that exposed one of the largest corruption schemes ever unveiled, Operation Car Wash (Watts, 2017).

The Prosecutor's Office, the bodies of internal and external control of the public administration and the Judiciary itself each underwent evolution that also contributed to these investigation efforts, which were made notorious with Operation Car Wash (2014 2021). The Supreme Court's decision to bar companies from making financial donations to political campaigns perhaps had the greatest impact in advancing financial equality between candidates. The judges sought to "correct the pathologies that distort the representative system" and to clear the "channels of expression and political participation" (Supreme Court of Brazil, 2015). To the Court, it was clear their responsibility was to bring back the 
PAP

24,1

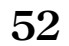

importance of the voters to the elections system, at a time that was overshadowed by corporate donations. The decision should be capable of mitigating the "capture of politicians by the economic power, which created an unwanted 'plutocratization' of the political process" (Supreme Court of Brazil, 2015). The judicial review suit was initiated by the Brazilian Bar Association and received support from many social groups.

The progress in the fight against corruption in Brazil is far from consistent and the success of reforms over the last decades remains uncertain. In recent years, Brazil has fallen in the Transparency International corruption perceptions index and, today, it occupies the $105^{\text {th }}$ place among 180 countries. Brazilians' trust in political institutions has reached an all-time low (Brazilian Institute of Public Opinion and Statistics, 2017), which puts the democratic stability at risk.

According to Carvalho (2008), Brazil has been dealing corruption since colonial times, but the concept of corruption has changed. The author argues that besides its moralistic conception, corruption is also political and systemic - it is embedded in the political system, in its functioning and in its logic. Thus, a vast range of literature will defend that Brazil's corruption is not explained by the absence of a control system - mainly after the return of democracy and the 1988 Constitution - but arises from various structural causes.

There are many theoretical perspectives that explain the origins of corruption and why it continues even after institutional remedies are implemented. Some of them relate to Brazilians' tolerance or cynical ignorance towards corruption (Silva, 1999). Other elements frequently linked to corruption are the technical advances and "professionalization" of corrupt activities, the impunity as the rule and the development of a clientelist Congress, among others.

Some recent literature argues that the moralist view - which accepts corruption as a cultural feature of Brazilian citizenship - is intangible and hard to be measured. So, two theoretical perspectives are presented to address the problem: one centred on patrimonialism and another on the rent-seeking perspective (Pinho and Sacramento, 2018). The first understands that corruption in Brazil can be explained by patrimonialism, which was not eradicated by industrialization in the country. According to this perspective, Brazil's political structures are too conservative to succumb to industrialization. So, it seems possible that the modernizing forces in the economic sphere are always trying to mould the conservative political forces, but in fact conservative politics resist the modernizing economy. This approach subsists with the rent-seeking theories, which became hegemonic after the implementation of "economic neo-constitutionalism" in Brazil during the 1990s.

In short, Pinho and Sacramento (2018) aim to attest that in the patrimonial system, as seen in Brazil, agents' actions are permeated by a confusion between the public and the private, which facilitates the plunder of the public by the actors - based on a fragile civil society. Besides that, they assert that the Brazilian limited and non-institutionalized democracy gives space to develop more active institutions, such as clientelism, patrimonialism and corruption.

Brazil has developed important domestic legislative instruments and adopted many international legal instruments to tackle corruption, but this apparatus has failed, so far, to effectively curb corruption. It is not easy to respond to the causes of this failure, but the socio-political literature, as we briefly exposed, has presented some interesting perspectives to better comprehend the problem and its origins in Brazil, as well as the difficulties in overcoming the current situation.

\section{International law in the Brazilian legal system: the links between corruption and human rights}

Brazil has adopted international legal instruments aimed at fighting corruption, such as: (a) the Organization for Economic Co-operation and Development (OECD) Convention on Combating Bribery of Foreign Public Officials in International Business Transactions; (b) the 
Organization of American States (OAS) Inter-American Convention against Corruption; and (c) the United Nations Convention against Corruption. Therefore, at least formally, Brazil takes part in the most relevant international legal systems available for states in the Americas aimed at fighting corruption, although their effective domestic implementation still faces significant challenges (Meyer-Pflug and Oliveira, 2009).

Similarly, Brazil is considered a country with a high commitment to international human rights. It has ratified 16 of the 18 main international treaties and protocols. Regarding the Organization of American States (OAS) treaties, Brazil is part of the main human rights treaties. For the purpose of this article, two international human rights treaties will be relevant: The International Covenant on Civil and Political Rights (ICCPR) and the American Convention on Human Rights (ACHR), both recognized as important international references in the protection of political participation and democratic rights.

Although there are solid legal instruments in the Brazilian legal system aimed at fighting corruption and there is significant adherence to international human rights law, few formal connect between these two sets of norms. Much of the literature that examines corruption, its causes and effects from a political or economic viewpoint, looks at its consequences on a country's political or economic wellbeing. Therefore, the human rights perspective has been left out of discussion, although as remarked by Pearson (2001, p. 30), "essentially, the fight against corruption and the fight for protection of human rights both rest on the need for accountable, representative government committed to equality and transparency".

While human rights standards have been recognized as a legitimate international concern (as a result of the notion of universalism in Human Rights theory), the corruption issue is largely viewed as a domestic political issue which is the responsibility of individual states to address. This may be a possible explanation for the lack of dialogue between the issue of corruption and its effects on fundamental human rights, a problem that can only be overcome by the guarantee of international human rights instruments allied to the enforcement of domestic anti-corruption law, along with the recognition of the intrinsic relation between them.

Corruption manifests itself in different ways and under different circumstances, but it can always be seen as a contributing factor to ongoing inequalities, by undermining social welfare, aggravating poverty and affecting the integrity of the political system. That is, corruption implies disrespect for human rights and prevents the development of democracy, whether it is a direct, indirect or remote cause for the violations. Gebeye (2012) affirms that corruption may be directly related to a human rights violation when the act is deliberately focused on violating a right; it can be an indirect cause when the corrupt act is an essential factor contributing to a chain of events that leads to a violation, and it can be a remote cause when it is one factor among others that contribute to human rights violations. As argued by Gebeye (2012, p. 26), "conversely, wherever human rights are not protected, corruption is likely to flourish".

In the last decades, there have been several developments among organizations that brought the issue of corruption onto the international agenda. As we can see, Brazil has been following this path by adopting the main international legal instruments aimed at fighting the problem. At the same time, Brazil has also ratified the main treaties on human rights and has even made an important step forward in its domestic legal system by addressing the issue of corporate corruption and its relation with human rights. In the next section we will explore specifically the political rights aspects of corruption, using mainly the Car Wash case as a reference.

\section{Corruption and political rights: the Operation Car Wash case}

Corruption and human rights connect on many levels. Corruption obstructs - locally and globally - the promotion of human rights and may be linked to the misappropriation of 
PAP

24,1

54

resources originally allocated for funding public policies, the weakening of laws and institutions' credibility, the distortion of the justice systems, the interference in the political process and the capacity of public services.

As for Brazil, it would also be possible to argue for the existence of multiple state actions or omissions that would invariably breach commitments taken on by the state with regards to guaranteeing human rights. Corruption is directly linked to poverty, because it feeds the cycle of unequal distribution of power and wealth. This is, among other factors, due to the misappropriation or concentration of financial resources that should be used to promote public policies and to guarantee the fundamental social rights established in the Constitution (Leal and Ritt, 2017, p. 155).

Systemic corruption in Brazil might be emblematic regarding its impact on social rights. According to the 2008 São Paulo State Federation of Industries Corruption Report (FIESP, 2012), $27 \%$ of the resources spent by the state on education was lost due to corruption. Regarding the volume of resources spent on health, it is estimated that corruption amounts to $40 \%$ of all public investments in this area. However, though the analysis of the ties between social human rights and corruption is very important, this particular work focuses on evaluating the context of the violations of rights of political participation.

The literature indicates the difficulty that lies in linking breaches of human rights with incidences of corruption. According to Pearson (2001, p. 51), "the difficulties encountered in answering the question as to whether corruption can lead to human rights violations may well be one of the reasons why it has not been adequately addressed in the past". Thus, this article aims to contribute and present by means of a case assessment, Operation Car Wash, in order to debate the macro context in which this case is inserted - the illegal campaign financing - and demonstrate the evidences that link this operation to the violation of specific fundamental human rights: the political rights.

\section{Operation Car Wash}

Throughout 57 operations (until December 2018 - the operation continued beyond this date), Operation Car Wash became "the largest investigation of corruption and money laundering that Brazil ever had". Considering the operation on the trial court level, only in its state of origin, Paraná (currently it actively operates in several states of the country), there were refund requests of US $\$ 10$ billion, 1,072 arrest warrants have been issued and 11 leniency agreements have been signed. In the Supreme Court (STF), which has original jurisdiction only regarding the authorities that benefit from special jurisdiction, 193 inquiries were opened, and 100 members of parliament, senators and ministers were charged.

The operation received significant popular support precisely because the judiciary - or most of the judges with jurisdiction over the cases - played a role that was generally expected from them. By punishing political agents that occupied important public offices, it signalled that the judiciary could effectively hold them accountable for corruption. Prosecuting hundreds of politicians and businessmen sent a message that the judiciary could after all end the impunity for corruption crimes.

\section{Illegal campaign financing and its interference in Brazilian democracy}

The complex structure set up for diverting resources from Petrobras to electoral campaigns made these campaigns highly competitive. One of the construction companies involved, Odebrecht, made at least 645 illegal contributions to politicians, totalling US\$64 million, between 2008 and 2014 (Taiar, 2017). In turn, the meat company JBS, which held the record for campaign donations in 2014, flooded the electoral process with approximately US $\$ 156$ million, of which US $\$ 113$ million were in official donations and US\$37 million were in cash payments or directed to companies appointed by politicians (Escosteguy, 2017). 
Statistically, one of the determinant factors of success in election campaigns is the volume of resources spent by candidates and their parties. Usually, the more expensive the campaign, the greater the chances of success in the election. When analysing the result of the elections in light of the funding received, the winning candidates invariably receive several times the average amount of other competitors. Illegal resources were donated and officially declared in a kind of money laundering via electoral campaign - as well as lawful money distributed to the campaigns via slush fund. Civil society organisations and the Electoral Justice are usually unable to monitor the abuse of economic power on the electoral dispute.

Even in contexts such as the one that existed in Brazil, the relationship between financing and election success is not of absolute causality. A greater volume of resources allows for a campaign to have more reach and more sophistication, possibly resulting in a broader influence on voters. However, one must consider the possibility that "candidates with more chances to be elected attract more resources. In this case, we would have a kind of reverse effect, in which the expected success in elections generates more funding” (Speck, 2012, p. 77).

Therefore, the Brazilian elections in the two decades before the Supreme Court ruling that blocked companies' electoral donations in 2015 were characterised by a strong imbalance of financial contribution by the companies that were later investigated. In this context, it is reasonable to say that some degree of distortion of the election results should have occurred, which allows us to establish a direct link between the distribution of the resources obtained through corruption and the violation of the political rights of Brazilian citizens.

\section{Human rights and the right to political participation}

Political rights are often seen by their best known and most evident aspect: the right to vote and to be elected. But the two main human rights treaties that bind Brazil on the matter of political rights - the ICCPR and the ACHR - bring to the discussion other comprehensive rules with an equally important effect on democracies. Article 25 of the ICCPR divides the right of political participation into three rules: (i) to take part in the conduct of public affairs, directly or through freely chosen representatives; (ii) to vote and to be elected at genuine periodic elections by universal and equal suffrage and held by secret ballot, guaranteeing the free expression of the will of the electors; and (iii) to have access, on general terms of equality, to public service in the country.

Article 23 of the ACHR has very similar wording, and also establishes rules of: (i) taking part in the conduct of public affairs, directly or through freely chosen representatives; (ii) voting and being elected in genuine periodic elections, which shall be by universal and equal suffrage and by secret ballot that guarantees the free expression of the will of the voters; and (iii) access, under general conditions of equality, to the public service of the country.

The conduct of public affairs is "a broad concept which relates to the exercise of political power, in particular the exercise of legislative, executive and administrative powers. It covers all aspects of public administration, and the formulation and implementation of policy at international, national, regional and local levels", according to the Covenant's Human Rights Committee (1996), a quasi-judicial body which is in charge of conducting cases that arise from individual complaints and of interpreting the Covenant.

The presence of large amounts of illegal resources in the Brazilian elections and politics in recent years has weakened the way in which public affairs are directed or conducted. This is because a few companies and individuals exert influence on State affairs in an unequal proportion compared to the vast majority of individuals who simply have a single vote. In this sense, "trading in influence in an election process infringes upon the free expression of the will of the electorate, and as such, violate the rights of all citizens, be they voters or candidates" (Terracino, 2007).

Thus, abusing the right to conduct or direct public affairs can be characterized in at least two ways: first, the concentration of most of the private funding of elections in a few donors - which origin is most often illegal - results in the establishment of privileged bridges 
PAP

24,1

of trust and access to elected representatives. Politicians become accountable to those who vastly increase their chances of electoral success and not to a diffuse electorate.

The second form of violating right to conduct public affairs occurs in the transformation of political priorities. On the one hand, bridges of special access are established from the moment the financial contribution is made (which could be legal or illegal, as long as they are bulky). On the other, there will be enormous pressure for the political agenda and government projects to coincide, at least in part, with the projects of the donors. Even if there is no specific request, agreement or any explicit illegality, the mere fact that a particular political agent will need financial support in the next electoral cycle is sufficient to transform their agenda to include actions leading to new donations in future elections.

Take the two mega-events promoted by Brazil, the FIFA World Cup in 2014 and the Rio de Janeiro Olympics in 2016 as examples. In both cases, there was a critical debate in Brazil as to what would be the best use of public resources, whether for building sports arenas or for basic public services. Coherent and defensible arguments exist on both sides of this difficult policy question. But the path adopted by the State, to pay for part of the mega-events infrastructure, has resulted from the potential future impact of such an investment, or it may have been a merely pragmatic calculation that choosing to have large construction works would mean favouring the financiers who, in turn, will have more resources available for future donations. Substituting voters' political priorities with donors' priorities is perverse and once again removes from the population the right provided for in articles 23 and 25 of the ACHPR and ICCPR, respectively, to conduct or to direct public affairs.

Another aspect included in the protection of political participation is the exercise of voting in authentic elections. To define authentic elections is not a simple and objective exercise. After all, how does one measure the authenticity of an election? Would only obvious fraud disfigure legitimate political participation? Or could one consider that elections which include excessive illegal financial resources also compromise authentic popular will for the reasons discussed above?

According to the Human Rights Committee (1996), Article 25 of the ICCPR "lies at the core of democratic government based on the consent of the people and in conformity with the principles of the Covenant" and must be interpreted in its broadest and most protective sense of the democratic process. The Committee also issued its opinion on the destructive potential of excessive resources (or illegal resources) in elections:

Voters should be able to form opinions independently, free of violence or threat of violence, compulsion, inducement or manipulative interference of any kind. Reasonable limitations on campaign expenditure may be justified where this is necessary to ensure the free choice of voters is not undermined or the democratic process distorted by the disproportionate expenditure on behalf of any candidate or party (Human Rights Committee, 1996).

Although this excerpt recommends an interpretation favourable to the possibility of imposing restrictions on legal election funding, its logic applies to cases with illegal resources. The aim of item "b" of Article 25 of the ICCPR is to ensure that the "free choice of voters is not undermined, or the democratic process distorted by disproportionate expenditure on behalf of any candidate or party", whether legal or illegal. The protection is aimed against the excessive resource, without specifying its origin (Human Rights Committee, 1996).

\section{Does the fight against corruption violate the political rights of the citizens being investigated?}

The beginning of this article explored the predominant perception of Brazilians about the impunity associated with corruption as the main challenge in the anti-corruption agenda. Regardless of the importance of preventive measures, which could block future cases of corruption, in recent years a certain civic impatience directed towards the judiciary - 
especially the collegiate courts - has become more perceptible as have the difficulties in holding politicians accountable for crimes against the public administration.

In this context of public frustration, the performance of the then federal judge of the $13^{\text {th }}$ Federal Criminal Court of Curitiba, Sergio Moro, stood out quickly. Acting as head of a court specialized in financial crimes and money laundering, he became nationally known for rigorously conducting the trials brought to him by an equally prominent task force of federal prosecutors and the federal police. The most prominent case was undoubtedly the judgment of the former President, Luiz Inácio Lula da Silva.

Lula's trial sparked a major debate in the country over whether the national expectation of fighting impunity and the proximity of the elections was the actual reason why his trial reached a second degree conviction faster than the average time for similar cases. And, according to his attorneys and to his supporters, led to his unjust criminal conviction. The arrest of former President Lula was surrounded by controversy. A Supreme Court justice, speaking to the press after the arrest and before the case reached the Court, said the prison "violates the Constitution" (Mello, 2018). There were also expressions of international solidarity to the former president, such as referring to the prison as "unjust and bias" (ElPaís, 2018). The lawsuits against Lula thus became the official point on the debate around human rights and corruption, but from the procedural fairness standpoint of the defendant instead of the society.

In response to the arguments of Lula's lawyers, the country debated whether the STF's understanding should be upheld, allowing for the execution of the prison sentence after conviction in the appeals court, even if the prosecution has not yet come to an end. It was also debated whether Lula could run for president after being convicted in the appeals court and therefore being a case of impediment according to the Clean Slate Act (Complementary Law 135 of 2010), which allowed the electoral court to prevent registration when the candidate had been convicted by a collegiate court of a specific set of crimes indicated in 21 subsections (Whitaker, 2016). The Lula case also led to a complaint before the Human Rights Committee (2017), based on the allegation that Sergio Moro was not an impartial judge, that his arrest was arbitrary and that his rights to be presumed innocent and to have his privacy preserved had been violated (Communication No. 2841/2016, submitted to the Human Rights Committee under the Optional Protocol to the International Covenant on Civil and Political Rights, in favor of Mr. Luiz Inácio Lula da Silva).

Lula's claim has not yet been analysed on its merits, but the Committee (2018) issued, in August 2018, an interim measure concluding that he should be able to exercises all his political rights while in prison and allowed to compete in the 2018 presidential elections until the judgment becomes final.

In response to the Committee's measure, the Superior Electoral Court dismissed the Committee's interpretation and voted for Lula's ineligibility. The ruling vote was that of judge Luís Roberto Barroso, which carried the understanding that the ineligibility of Lula was derived from the Clean Slate Act in the face of his criminal conviction. The great surprise of the trial was judge Edson Fachin's dissenting vote, in favour of authorizing the candidacy of Lula. The vote acknowledged both the effectiveness of Committee's interim measure and Lula's right to political participation as noted in Article 25 of the ICCPR (Human Rights Committee, 1996).

The trial of former President Lula is now part of the debate that deals with the relationship between corruption and human rights. Davis (2019), for example, affirms that the connections between corruption and human rights violations are contingent, and must be analysed case by case. The author highlights that "implementation of anti-corruption policies can cause, rather than prevent, human rights violations. It is not uncommon for anti-corruption law to be used to violate due process rights or to persecute champions of human rights" (Davis, 2019, p. 3). In other words, the author asserts that human rights violations can be directed towards citizens that, somehow, stand against systemic privileges or seek to combat social inequalities. That is precisely what former President Lula's supporters argued. 
PAP

24,1

58

The outcome of this case is far from obvious and has mobilized various political forces in Brazil over the past years. The implication was that Operation Car Wash has awakened and united the political left sector against the judicial protagonists that prevented Lula from running in the 2018 presidential elections. The episode in which the Lula family's private conversations were illegally revealed by the casés judge is a common point for criticism and a source of legal vulnerability of the entire operation. The discussion has gained more nuances after Operation Car Wash's leading judge Sergio Moro joined the new president elect and Lula's rival, Jair Bolsonaro, as his Minister of Justice. Furthermore, the recent disclosure of dialogues between the chief prosecutor of Operation Lava Jato in Curitiba and judge Sérgio Moro, obtained illegally through the hacking of the prosecutor's phone, brought new elements that indicate the partiality of the judge in relation to defendant Lula.

\section{Conclusion: the legacy of Operation Car Wash and the right to political participation}

Operation Car Wash has ended and there is little doubt about the impact it produced and the perspective it created for a new standard of investigating and punishing. It will also be remembered by illegalities, biased investigations and decisions in some of its cases. However, it remains unclear whether it will leave behind a legacy of lasting legislative reforms and innovative practices in investigation.

The Brazilian citizens were victims of corruption. The Brazilian State did not comply with several commitments made in international human rights treaties because it was not able to keep corruption at a minimum level. Brazil gained an international reputation for its cases of corruption, just as it once did because of football. In Brazil, corruption does not occur sporadically, but develops as a systemic, organized web, as was discovered with Operation Car Wash.

The lack of effectiveness of the anti-corruption measures taken so far can be explained by the socio-institutional limits that, for centuries, have been drawing the dynamics of national politics. The institutional constraints of Brazil's political system require politicians to adapt themselves to the rules of the game. It was expected that Operation Car Wash would open a new chapter in national politics, since it has been uncovering the corruption networks that have dictated the Brazilian politics for years.

Just as the causes of corruption are complex and varied, so too are the effects. The central argument of this text is that political rights have been deeply affected in recent years by the lack of effective control over the inflow of excessive financial resources into the electoral process. As a result, elections were potentially biased in favour of candidates that received illegal financial resources and, consequently, it was impossible for citizens to fairly participate in public affairs.

To reach this conclusion, it has been demonstrated that Brazilian anti-corruption legislation has advanced in recent years, without being able to face the serious impunity that protects those involved in corruption. Car Wash represented a break from this perception and paved the way for confronting the systemic corruption that permeates the entire Brazilian political system. Political rights lie amid a conflict of narratives: society expects elections without the bias caused by illegal resources, but the defendants in these same corruption prosecutions also expect to see their political rights protected against strong punishing expectations.

The paper has argued that corruption in Brazil is a systemic problem, thus overcoming it requires not only political change, but also legislative and judicial reforms. The paper also described some of the recent multi-institutional efforts implemented in recent years. Therefore, this article intended to show that besides Operation Car Wash, some important legislative measures - such as the Clean Slate Act - and crucial judicial decisions such as the Supreme Court ban on corporate election funding - are part of the same complex moment in which anticorruption efforts have been developing. Despite the legal developments that permitted Operation Car Wash to advance, a window of opportunity remains open, waiting for a new 
generation of legislative reforms that can consolidate successful practices in investigating corruption, as well as strengthening peoplés political rights against electoral corruption.

\section{ORCID iDs}

Michael Freitas Mohallem Dhttp://orcid.org/0000-0002-1173-796X
Electoral corruption and political rights

\section{References}

Avritzer, L. and Filgueiras, F. (2011), "Corrupção e controles democráticos no Brasil" (Corruption and democratic controls in Brazil), Textos para Discussão CEPAL-IPEA, available at: https:/www. ipea.gov.br/portal/images/stories/PDFs/TDs/td_1550.pdf (accessed 21 February 2021).

Brazilian Institute of Public Opinion and Statistics (2017), "Confidence in the president, federal government and National Congress is the lowest in 9 years", available at: http:/177.47.5.246/ noticias-e-pesquisas/confianca-no-presidente-governo-federal-e-congresso-nacional-e-a-menorem-9-anos/ (accessed 30 October 2020).

Carvalho, J.M. (2008), "Passado, presente e futuro da corrupção brasileira” (Past, present and future of Brazilian corruption), in Avritzer, L., (Ed.), Corrupção: ensaios e críticas (Corruption: essays and criticisms), UFMG Publisher, Belo Horizonte, pp. 200-205.

Davis, K.E. (2019), "Corruption as a violation of international human rights: a reply to Anne Peters", European Journal of International Law, Vol. 29 No. 4, pp. 1289-1296.

El País (2018), "Ten international jurists denounce 'injustice and bias' in the Lula case", available at: https://brasil.elpais.com/brasil/2018/08/09/politica/1533836703_194165.html (accessed 20 January 2019).

Escosteguy, D. (2017), “As provas da JBS” (The evidences of JBS), ÉPOCA Magazine, 29 July, available at: https://epoca.globo.com/politica/noticia/2017/07/provas-da-jbs-trecho.html (accessed 15 May 2020).

Federal Prosecutor's Office (n.d.), "Lava Jato: entenda o caso" (Car Wash: understand the case), available at: http://www.mpf.mp.br/grandes-casos/caso-lava-jato/endenda-o-caso (accessed 15 May 2020).

Federation of Industries of the State of São Paulo (FIESP) (2012), "Relatório Corrupção: custos econômicos e propostas de combate" (Corruption Report: economic costs and proposals to confront), available at: https://www.fiesp.com.br/indices-pesquisas-e-publicacoes/relatoriocorrupcao-custos-economicos-e-propostas-de-combate (accessed 15 May 2020).

Gebeye, B.A. (2012), "Corruption and human rights: exploring the relationships”, Human Rights and Human Welfare Working Papers, available at: https://www.du.edu/korbel/hrhw/workingpapers/ 2012/70-gebeye-2012.pdf (accessed 15 May 2020).

Human Rights Committee, United Nations (1996), "General Comment No. 25: The right to participate in public affairs, voting rights and the right of equal access to public service (Article 25)", available at: https:/undocs.org/ar/CCPR/C/21/Rev.1/Add.7 (accessed 21 February 2021).

Human Rights Committee, United Nations (2017), "Interim Measure, G/SO 215/51 NRA (1), 2841/2016”, available at: https://www.ohchr.org/en/NewsEvents/Pages/DisplayNews.aspx?NewsID=23464 (accessed 21 February 2021).

Leal, R.G. and Ritt, C.F. (2017), "As consequências negativas da corrupção nos direitos sociais fundamentais no Brasil: as pessoas mais pobres como as principais vítimas" (The negative consequences of corruption on fundamental social rights in Brazil: the poorest people as the main victims), Revista de Direito e Desenvolvimento, Vol. 8 No. 1, pp. 107-128.

Lorente, M. (2016), "Corrupção no Brasil e estratégias de combate" (Corruption in Brazil and combat strategies), Revista Brasileira de Estudos da Função Pública, Vol. 5 No. 14, pp. 203-257.

Mello, M.A. (2018), "Prisão de Lula é 'ilegal' e 'viola a Constituição', diz ministro do Supremo Tribunal Federal" (Lula's arrest is 'illegal' and 'violates the Constitution', says Supreme Court justice), 
PAP

24,1

available at: https:/www.poder360.com.br/justica/prisao-de-lula-e-ilegal-e-viola-a-constituicaodiz-ministro-do-stf/ (accessed 20 Jan 2019).

Meyer-Pflug, S.R. and Oliveira, V. (2009), "O Brasil e o combate internacional à corrupção" (Brazil and the international fight against corruption), Revista de Informação Legislativa, Vol. 46 No. 181, pp. 187-194.

Mohallem, M.F. and Ragazzo, C. (2017), "Diagnóstico institucional: primeiros passos para um plano nacional anticorrupção" (Institutional review: first steps towards a national anti-corruption plan), available at: http://bibliotecadigital.fgv.br/dspace/handle/10438/18167 (accessed 15 May 2020).

Pearson, Z. (2001), "An international human rights approach to corruption", in Larmour, P. and Wolanin, N. (Eds.), Corruption and Anti-Corruption, Australian National University Press, Canberra, pp. 30-61.

Pinho, J.A.G. and Sacramento, A.R.S. (2018), "O círculo vicioso da corrupção no Brasil: limites estruturais e perspectivas de rompimento" (The vicious circle of corruption in Brazil: structural limits and prospects for disruption), Public Service Magazine, Vol. 69, pp. 181-209.

Silva, M.F. (1999), "The political economy of corruption in Brazil", RAE-Revista de Administração de Empresas, Vol. 39 No 3, pp. 26-41.

Speck, B.W. (2012), "O financiamento político e a corrupção no Brasil" (Political financing and corruption in Brazil), in Biason, R. (Ed.), Temas de corrupçãa política no Brasil (Political Corruption Issues in Brazil), Balão Editorial, São Paulo, pp. 49-97.

Supreme Court of Brazil (2015), ADI 4650-DF, Rapporteur Luiz Fux, full decision published on 24 February 2016, available at: http://portal.stf.jus.br/processos/detalhe.asp?incidente $=4136819$ (accessed 21 February 2021).

Taiar, E. (2017), "Veja lista de políticos que teriam recebido caixa 2 da Odebrecht" (See the list of politicians who would have received slush funds from Odebrecht), Valor Econômico, 14 April, available at: https://www.valor.com.br/politica/4938504/veja-lista-de-politicos-que-teriamrecebido-caixa-2-da-odebrecht (accessed 15 May 2020).

Terracino, J. (2007), "Hard law connections between corruption and human rights", working paper presented on 2007 International Council on Human Rights Policy Review Meeting, Geneva, available at: http://www.ichrp.org/files/papers/130/131_-_Julio_Bacio_Terracino_-_2007.pdf (accessed 15 May 2020).

Watts, J. (2017), “Operation Car Wash: Is this the biggest corruption scandal in history?”, The Guardian, 1 June, available at: https://www.theguardian.com/world/2017/jun/01/braziloperation-car-wash-is-this-the-biggest-corruption-scandal-in-history (accessed 20 January 2019).

Whitaker, C. (2016), "Ficha Limpa - uma lei a defender?” (Clean Slate Act - a law to fight for?), Estudos Avançados, Vol. 30 No. 88, pp. 231-245.

\section{About the author}

Michael Freitas Mohallem is Human Rights Law lecturer and Head of the Centre for Justice and Society at Getulio Vargas Foundation Law School, Rio de Janeiro, Brazil. He is a $\mathrm{PhD}$ candidate in Law at the University College London (UCL) and holds a LLM in Public Law and Human Rights from UCL, a postgraduate degree in Political Science from the University of Brasília and a LLB from the Catholic University of São Paulo. He was visiting researcher at the European University Institute and visiting scholar at the Minerva Center for Human Rights at Hebrew University of Jerusalem. He has previously worked as legal advisor in the Brazilian Senate and in the Brazilian Ministry of Justice. Michael Freitas Mohallem can be contacted at: michael.mohallem@fgv.br

For instructions on how to order reprints of this article, please visit our website:

www.emeraldgrouppublishing.com/licensing/reprints.htm

Or contact us for further details: permissions@emeraldinsight.com 